\title{
Relevance of Organic Farming in Ethiopian Agriculture: Mission and Commitment with Second Green Revolution
}

\author{
Kibebew Kibret Tsehai and Bipin B Mishra* \\ School of Natural Resources Management \& Environmental Sciences, Haramaya University, Ethiopia
}

Submission: January 09, 2017; Published: August 28, 2017

"Corresponding author: Mishra BB, School of Natural Resources Management \& Environmental Sciences, Haramaya University, Ethiopia, Email: bbmsoil@rediffmail.com

\begin{abstract}
Agriculture, with almost equal share of the twin farming systems of crop production and livestock development, characterizes the key issues of Ethiopian economy. The first green revolution could not have got its momentum in Ethiopia due to limitations associated mainly with improved varieties, assured irrigation and, inorganic fertilizers. The continued efforts in crop varieties improvement, inventorying of soil resources, watershed development, and related activities have now amplified the potential of Ethiopia to revolutionize its agricultural developments both livestock and crop productions. However, the message from the first green revolution in terms of soil health deterioration leading to malnutrition, polluted foodstuff and water and other types of contamination of agricultural products due to excessive use of inorganic fertilizers, chemicals, insecticides and pesticides has bitterly warned the scientists and even planners to move to some compromise in the use of inorganic materials as inputs. The use of organic resources alone or in integration with inorganic materials is the quick answer to such compromise. Needless to mention, the use of organic resources for soil fertility management is virtually known almost since the beginning of agriculture. In the same fashion, the present human population world-wide wants food stuff free of pollution, contamination or even adulteration caused by unwise and unscientific use of inorganic fertilizers and other agricultural chemicals, which were the main bearing to the yield increase during the first green revolution at the expense of the quality of the produces. The second green revolution relates to restoration of quality of produce and improvement of soil health and quality. Obviously, organic farming approach is the only option for its realization. The quality of organic resources and their fertilizer equivalence are the main criteria to be judged for effective utilization of the organic resources for soil fertility improvement and promotion of agricultural products both in quantity and quality. The contents of organic carbon, total nitrogen, lignin, polyphenol and C:N ratios are some of the basic parameters to be considered in quality assessment of the organic resources. Under natural environments, there are many plant species that are useful to soil fertility improvement, but our knowledge is limited. Knowledge of organic matter turnover in soils is of vital importance in order to estimate the amount of organic resource to be added to soils to maintain the organic matter status. Soils with high C: $\mathrm{N}$ ratio need to have very specific management practices. The enhancement of $\mathrm{N}$ and $\mathrm{P}$ status of soils with exposures to X-rays is recently established for further validation as well as application either in field or otherwise. The clue of second green revolution lies on quality improvement of agricultural produces and this could be achieved by how could the integration of organic resource with very selective amount of inorganic fertilizers be made effective for high yields without any scope of abuse due to degradation. The considerable demand and relatively higher market values of the organically produced crop as well as livestock products for being free from pollution, high quality and healthy foodstuff are obviously positive additives and better bargaining power in the compromises with the possible reduction in quantity of yield in the short term from minimizing the use of mineral fertilizers and other agricultural chemicals.
\end{abstract}

Keywords: Ethiopian agriculture; Inorganic fertilizers; Organic farming; Organic matter/sources; Second green revolution

\section{Introduction}

Soil formation as a result of weathering of rocks and minerals begins with microbial colonization on rock. In fact, the rock surface is initially colonized by the lichen, a symbiotic association of algae and fungi, wherein algae may fix atmospheric nitrogen, photosynthesize their organs and provide organic substrates for the growth of fungi [1], which is already discussed in Photopedogenesis. Fungi on subsequent growth facilitate chemical reaction with rock surface materials by forming organic acids and providing more nutrient environment for algae. With such mutual contributions made by both algae and fungi, a thin soil layer starts to develop on the rock surface. Following lichen is moss and then higher plants as rightly narrated by Cresser 
et al. [1]. This simple example justifies the relevance of organic matter as well as microorganisms in soils and their interactions to enrich soil fertility.

In Ethiopia, irrigated land is practically insignificant and the entire agriculture is dependent on rainfall. The distribution of rain is. Undulating physiography coupled with arrays of hilly terrains with steep slopes result in moisture stress in topographic highs and moisture excess in topographic lows $[2,3]$. Moisture being the most important input for improved cultivation; it appears to be the most limiting farming input in Ethiopia. Besides, the nutrient depletion in Ethiopian soils has been rated to be the highest in sub-Saharan Africa. The average losses of $\mathrm{N}_{2} \mathrm{P}_{2} \mathrm{O}_{5}$ and $\mathrm{K}_{2} \mathrm{O}$ from Ethiopian soils are greater than 40,15 and $40 \mathrm{~kg}$ per hectare (ha) per year, respectively [4]. Moreover, the current fertilizer application rate in Ethiopia, mostly on sporadic basis [5], has not exceeded a total of $20 \mathrm{~kg}$ of N-P ha-1, which is far below the minimum requirement for replenishment of already depleted nutrients. Furthermore, the country has been applying only $\mathrm{N}$ and $\mathrm{P}$ as fertilizers for the last many years despite the fact that recent analysis of surface soils indicated deficiency of many essential nutrients including $\mathrm{K}$ and micronutrients. Therefore, Ethiopian agriculture is virtually an organic farming system throughout the country except for some pockets and research farms intended to use inorganic fertilizers. Besides, except some fertilizer blending plants which are under construction, there is no fertilizer industry in Ethiopia and the entire fertilizer consumption is by and large imported causing huge foreign exchange.

In this context, one has to look for two sensitive issues critically before deciding what has to be done with the use of chemical (inorganic) fertilizers. The first issue is related to the provision of adequate chemical fertilizers to the farmers for boosting crop production provided that the crops are well supplied with water and other inputs for high yielding varieties. This is, however, challenging particularly in view of the fact that mineral fertilizers are among the expensive inputs especially when they are imported from abroad. The second issue is related to the response for the growing global concerns to the food pollution caused by exhaustive use of agricultural chemicals and fertilizers to grain and vegetable crops. In most of the agriculturally developed countries like Europe, North America, and India, the farming communities are abusing the use of fertilizers and chemicals on their farms. Unpublished reports show that in India, such continuous use of chemicals and inorganic fertilizers has now appeared in the form of cancer disease to the farming families besides other health problems. Consumers in these countries are becoming aware of the health hazards related to such products and have started looking for organically produced agricultural products despite their very high prices.

The above two issues are of immediate interest to Ethiopian context, where fertilizers as well as chemicals in agriculture are least appreciated until now by whatever reasons are emphasized. It is a crucial stage even for the Government to decide what would be the right direction in fertilizer policy of the country. The one way of positive considerations is to look for a nation in the map of the world where agriculture should be based dominantly on organic farming and where chemical fertilizers should be recommended only as starting dose for the quick nutrient supply to the plants. World people are looking for the food stuff grown without the use of fertilizers and other agricultural chemicals, and the Ethiopian products will surely be demand-driven internationally provided that concerted efforts are made to popularize and clearly justify why they are organic produces. Such demand will surely compensate the possible low yield caused by minimum use of inorganic fertilizers and other none organic inputs.

In real practices, farmers following traditional systems often use manures and crop residues in different forms. Currently, every farmer is advised to make compost from different locally available organic sources and apply the compost to his/her soil every cropping season in a bid to improve the health of the soil. The implementation of this is strictly followed and monitored by development agents assigned to peasant associations. However, the use of such organic nutrient sources is by and large non-scientific. Even the fertilizer inputs used under moisture stress (rain fed farming) areas suffer in their efficiencies and recoveries. Therefore, there is need to pay attention to organic farming through meaningful application of different organic resources of both plant and animal origins including farmyard manures, composts, crop residues, bone meals, coffee husk/pulp, other byproducts of agricultural processing plants and their scientific integrations with synthetic and mineral fertilizers on sustainable basis. This has also been emphasized by Wakene et al. [6] on their studies on the integrated use of farmyard manure and low rates of inorganic $\mathrm{N}$ and $\mathrm{P}$ fertilizers.

\section{Organic resources as the potential sources to promote soil fertility}

Table 1: Rating of organic matter and total nitrogen status of Ethiopian soils.

\begin{tabular}{|c|c|c|}
\hline Rating & Organic Matter (\%) & Total N (\%) \\
\hline Very low & $<1.0$ & - \\
\hline Low & $1.0-2.0$ & $<0.10$ \\
\hline Medium & $2.0-3.0$ & $0.10-0.16$ \\
\hline High & $3.0-5.0$ & $0.16-0.25$ \\
\hline Very high & $>5.0$ & $>0.25$ \\
\hline
\end{tabular}

Source: Murphy $[3,47]$ and several other authors

As a quick chemical assessment of soil fertility status in most of Ethiopian soils in relation to organic matter and total nitrogen, the rating given in Table $1[7,8]$ are often appreciated. However, these data lack scientific contents and are merely approximation. The evaluation of organic matter in soils depends on type and nature of organic source, ease of decomposition and overall soil and climatic environment. The data in Table 2 indicate the critical values of micronutrients in both soil and plants [9]. 
Table 2: Tentative critical values of micronutrients in soils and plants.

\begin{tabular}{|c|c|c|c|c|}
\hline \multirow{2}{*}{ Micro-Nutrient } & \multicolumn{2}{|c|}{ Soil (mg kg-1) } & \multicolumn{2}{|c|}{ Plant (mg kg-1) } \\
\hline & Deficiency & Excessive & Deficiency & Toxicity \\
\hline B & $<0.3-0.5$ & $<3-5$ & $<10-20$ & $>25-40$ \\
\hline $\mathrm{Cu}$ & $<0.8-1.0$ & $>17-25$ & $<2-4$ & $>10-15$ \\
\hline $\mathrm{Fe}$ & $30.0-35.0$ & Unknown & $<30-50$ & Unknown \\
\hline $\mathrm{Mn}$ & $<2.0-5.0$ & $<140-200$ & $<10-30$ & $>400-600$ \\
\hline Mo & $<0.01-0.02$ & $<0.5-1.0$ & $<0.09-0.70$ & $>0.2-1.5$ \\
\hline $\mathrm{Zn}$ & $<1.00-1.50$ & $<20-30$ & $<10-15$ & $>20-50$ \\
\hline
\end{tabular}

Source: Desta Beyene [11].

The soils of the highlands in most part of Ethiopia contain considerable amounts of organic carbon content $(>1$ percent) particularly in the surface layers under sub-humid climate. Most of the clay mineral suites indicate smectite or its interstratifications as the dominant minerals particularly when their genesis is associated with limestone and basalt parent rocks. Such clay minerals are susceptible to form the complexes with compounds of organic matter undergoing decomposition. This is meant that the organic materials can not undergo further decomposition and thus the formation of humus remains arrested. This further indicates that the soil organic matter remains partially decomposed and often provides some environment for the survival of insect larvae and others in the soils. Termite mounts (mounds) are frequently observed in different parts of Ethiopia. Interestingly, such mounts in Gode area (southeastern arid lowlands of Ethiopia) were found to be thick and very tall $(>3-4 m)$, whereas in Jijiga (eastern semi arid mid altitude) areas of Ethiopia, they were comparatively thin and medium in heights. The termite mounts are often used by mixing with the surface soil for improving soil fertility. Systematic study is awaited to give scientific explanation to the nutritional values of termite mounts.

Plant roots are strange in their total biomass present in soils. Based on a critical review of Knuti \& Williams [2], the total root dry weight of mature Pairie grass in the sub-humid climates of the temperate region may be as high as $2.03 \mathrm{t} \mathrm{ha}^{-1}$ in the plough depth of soil, whereas roots of cultivated grasses may be around $1.02 \mathrm{tha}^{-1}$ for blue grass and $0.61 \mathrm{t} \mathrm{ha} \mathrm{h}^{-1}$ for alfalfa. The same authors opined that the underground roots show approximately 130 times more surface area than that of above ground plant parts. Such data suggest that the roots have tremendous role to play in organic matter inputs to soils. Kang et al. [10] also discussed about the significance of alley farming in the process soil organic matter build-up in cultivated lands.

In areas of rain fed agriculture, Tithonia diversifolia was found to be a promising source of nitrogen in place of any mineral fertilizer [11]. However, Senna spectabilis and Calliandra calothyrsus green biomass may be recommended with inorganic $\mathrm{N}$ source for use in soils (Table 3). Kimetu et al. [11] opined that similar identification needs to be made for other organic materials. Annual application of high quality goat manure $(2.04 \%$ $\mathrm{N}, 0.48 \% \mathrm{P}$ and $25.62 \% \mathrm{C}$ ) at the rate of five tons per hectare was comparable to inorganic $\mathrm{N}$ and $\mathrm{P}$ on continuous cultivation of maize [12]. Decomposition of organic materials was higher in soils with low clay than in soils with high clay contents likely due to more microbial accessibility in low clay soils (pore size $>0.75 \mu \mathrm{m}$ ) and thus explained why high clay soils are better capable to protect the organic matter from decomposition [13].

Table 3: Average chemical composition of some plant materials.

\begin{tabular}{|c|c|c|c|c|c|c|c|c|}
\hline \multirow{2}{*}{$\begin{array}{c}\text { Plant } \\
\text { Material }\end{array}$} & \multicolumn{7}{|c|}{ Chemical Composition (\%) } & C: N ratio \\
\cline { 2 - 9 } & $\mathbf{N}$ & $\mathbf{P}$ & $\mathbf{K}$ & $\mathbf{C a}$ & $\mathbf{M g}$ & Polyphenol & Lignin & \\
\hline $\begin{array}{c}\text { Tithonia } \\
\text { diversifolia }\end{array}$ & 4.35 & 0.45 & 5.30 & 2.60 & 0.30 & 2.20 & 7.25 & 10.10 \\
\hline $\begin{array}{c}\text { Senna } \\
\text { spectabilis }\end{array}$ & 3.40 & 0.15 & 1.90 & 0.90 & 0.20 & 2.60 & 10.80 & 10.89 \\
\hline $\begin{array}{c}\text { Calliandra } \\
\text { calothyrsus }\end{array}$ & 2.80 & 0.10 & 0.85 & 1.10 & 0.30 & 11.15 & 15.95 & - \\
\hline
\end{tabular}

Source: Kimetu et al. [37].

In experiments on soil conservation and productivity, Leucaena leucocephala (agro-forestry alley leguminous plant) showed great potential in promoting soil fertility, whereas Calliandra calothyrsus (leguminous hedge plant on steep slope) effectively reduced soil and nutrient losses besides producing a large tonnage of biomass with high crude protein content that

could be used as forage [14]. According to Young [15], Leucaena and Gliricidia (Gliricidia sepium) showed $85 \%$ reduction in soil and nutrient losses on a $7 \%$ slope compared to conventional tillage. Nitrate loss could be controlled significantly by planting Calliandra calothyrsus and Sesbania sesban [16]. 


\section{Agricultural Research \& Technology: Open Access Journal}

Table 4: Nutrient element composition of crop residues and manure

\begin{tabular}{|c|c|c|c|c|c|c|}
\hline \multirow{2}{*}{$\begin{array}{l}\text { Organic Nutrient } \\
\text { Sources }\end{array}$} & \multicolumn{6}{|c|}{ Concentration of Nutrient Elements $\left(\mathrm{gkg}^{-1}\right)$} \\
\hline & $\mathbf{N}$ & $\mathbf{P}$ & $\mathbf{K}$ & $\mathrm{Ca}$ & Mg & $\mathbf{S}$ \\
\hline Manure & 3.43 & 0.97 & 1.75 & 6.40 & 1.70 & 0.49 \\
\hline Soybean residue & 28.47 & 3.19 & 17.40 & 15.30 & 2.65 & 2.33 \\
\hline Wheat residue & 9.03 & 1.33 & 9.75 & 4.30 & 0.80 & 1.38 \\
\hline Maize residue & 15.98 & 2.29 & 15.45 & 3.70 & 1.75 & 1.24 \\
\hline
\end{tabular}

Source: Kaboneka and Sabbe [31].

Tithonia decomposes faster than Senna and represents high quality residues $[17,18]$. The biomass of Tithonia and/or Senna was incorporated to the top soil during land preparation and the fresh biomass in required amount at the rate of $5 \mathrm{t} \mathrm{ha}^{-1}$ was weighed based on predetermined fresh weight to dry weight ratio and distributed on the field for mixing with soils. Plant residues are good sources of many nutrients that are applied either in place of or as a supplementary to chemical fertilizers to the crops according to their requirements. Chemical data expressed on a dry weight basis for different crop residues and organic manures (Table 4) suggest that the organic sources are selectively suitable for different nutrients to be supplied to crops. Organic manures, for example, are rich in nitrogen and calcium; whereas wheat residues are rich in nitrogen, potassium and calcium; soybean residues are potentially rich in nitrogen, phosphorus, sulfur, potassium, calcium and magnesium; and maize residues are rich in nitrogen, phosphorus, potassium and calcium [19]. The Tithonia diversifolia (agro forestry shrub species) was identified as an effective organic source for phosphorus build-up in soil as well as in plants. Tithonia also caused reduction in P sorption [20] and extractable $\mathrm{Al}$ and thus increased soil $\mathrm{pH}$ [21]. In fact, increase in microbial biomass was reported in Tithonia treatment [22].

Phosphorus in the Ethiopian soils poses different scenario wherein only a very low fraction of total soil $\mathrm{P}$ is available to plants [23]. Major fraction of the total P is in unavailable form. Paulos [23] reported that the highest amount of total soil P $(0.36 \%)$

least amount of total soil P (0.09\%) showed considerably high amount of soil available P $\left(27.19 \mathrm{mgkg}^{-1}\right)$. It was observed that the association of available $\mathrm{P}$ with that of total soil $\mathrm{P}$ is controlled by different soil factors and chemical environments. The ratios of Ca-P: Al-P: Fe-P during P-fractionation were found to be 1: 0.24-0.56: 2.02-4.27, respectively. Obviously, Fe-P in soil is highest followed by Ca-P and least is Al-P. Wakene \& Heluf [24], however, indicated irregular trends of different P-fractions of soil developed on basalt. Heluf \& Mishra [25], on the contrary, reported medium to high P-range in soils of Hirna eastern Ethiopia, with generally high C:N ratio values.

Soybean, maize and wheat residues were found to be important sources of $\mathrm{K}$ as about $40-50 \%$ of $\mathrm{K}$ was available from residues in a 70 days period [26]. The data in Table 4 indicate that the concentration of the basic cautions in the three crop residues were in the order of $\mathrm{K}>\mathrm{Ca}>\mathrm{Mg}$. Similarly, $\mathrm{K}$ and $\mathrm{Mg}$ release from applied residues [18] and in a similar study on foliar litter and forest floor dynamics in a Pinus resinosa stand [27] followed the order $\mathrm{K}>\mathrm{Mg}$. Blair [28] found that $91 \%$ of $\mathrm{K}$ and $58 \%$ of $\mathrm{Mg}$ were released after 2 years of decomposition. Among the major nutrient elements such as $\mathrm{N}, \mathrm{P}, \mathrm{K}, \mathrm{Ca}, \mathrm{Mg}$ and $\mathrm{S}$, potassium is only known to be non-structural component of plant tissue, moving freely in the cell fluid and so the potassium release from crop residues is less correlated with the biotic factors as compared to other nutrient elements [25]. It is for this reason that the potassium (K) ions are easily leached out of soils and rendered the symptom of deficiency in both soils and plants.

Table 5: Available potassium distribution in surface soils of Alemaya University farmland

\begin{tabular}{|c|c|c|c|c|c|}
\hline \multicolumn{3}{|c|}{ Location } & \multicolumn{3}{|c|}{ Available $\mathrm{K}\left(\mathrm{NH}_{4} \mathrm{OAC}\right.$-extractable) } \\
\hline Latitude (N) & Longitude (E) & Altitude (m amsl) & $\mathrm{mg} \mathrm{kg}^{-1}$ & kg ha $^{-1}$ & Range \\
\hline $9^{\circ} 25.090^{\prime}$ & $42^{\circ} 1.900^{\prime}$ & 2036 & 83.5 & 167 & Medium \\
\hline $9^{\circ} 24.713^{\prime}$ & $42^{\circ} 2.114^{\prime}$ & 2049 & 211 & 422 & High \\
\hline $9^{\circ} 24.725^{\prime}$ & $42^{\circ} 2.224^{\prime}$ & 2051 & 323.2 & 646.4 & High \\
\hline $9^{\circ} 25.080^{\prime}$ & $42^{\circ} 2.103^{\prime}$ & 2050 & 219.5 & 439 & High \\
\hline $9^{\circ} 25.045^{\prime}$ & $42^{\circ} 1.928^{\prime}$ & 2036 & 309 & 618 & High \\
\hline $9^{\circ} 24.919^{\prime}$ & $42^{\circ} 1.935^{\prime}$ & 2042 & 123 & 246 & Medium \\
\hline $9^{\circ} 24.642^{\prime}$ & $42^{\circ} 2.116^{\prime}$ & 2042 & 277.5 & 554 & High \\
\hline $9^{\circ} 24.769^{\prime}$ & $42^{\circ} 2.191^{\prime}$ & 2049 & 233.5 & 466 & High \\
\hline $9^{\circ} 24.862^{\prime}$ & $42^{\circ} 2.201^{\prime}$ & 2047 & 212 & 424 & High \\
\hline $9^{\circ} 24.627^{\prime}$ & $42^{\circ} 2.024^{\prime}$ & 2041 & 223.5 & 447 & High \\
\hline
\end{tabular}




\section{Agricultural Research \& Technology: Open Access Journal}

\begin{tabular}{|r|l|l|l|l|l|}
\hline $9^{\circ} 24.761^{\prime}$ & $42^{\circ} 1.929^{\prime}$ & 2042 & 287.5 & 575 & High \\
\hline $9^{\circ} 25.086^{\prime}$ & $42^{\circ} 2.163^{\prime}$ & 2051 & 249.5 & 499 & High \\
\hline $9^{\circ} 25.093^{\prime}$ & $42^{\circ} 1.940^{\prime}$ & 2037 & 266.5 & 533 & High \\
\hline $9^{\circ} 24.899^{\prime}$ & $42^{\circ} 2.221^{\prime}$ & 2048 & 184.5 & 269 & Medium \\
\hline
\end{tabular}

Source: Alemaya University (unpublished).

The soils of Ethiopia are known to contain sufficient amount of available $\mathrm{K}$ (water soluble, exchangeable and $\mathrm{HNO}_{3}$ - extractable $\mathrm{K})$. However, this cannot be taken as a thumb of rule as many soils had also been identified as deficient in available $\mathrm{K}[17,18]$. Thus, evaluation of the status of soil K should be considered in the soil fertility evaluation efforts. Further reports indicate that the K-status of the Ethiopian Rift Valley soils were adequate for crop production [29]. Direct soil application of organic materials may provide substantial amounts of potassium. Soybean, maize, and wheat residues were found to be important sources of $\mathrm{K}$ with $17.40,15.45$ and $9.75 \mathrm{~g}$ of $\mathrm{K} \mathrm{kg}^{-1}$, respectively, and about $40-50 \%$ of potassium was available from these residues in a 70 days period [13]. It is well documented that the soils of Ethiopia are by and large well supplied with potassium. Data in Table 5 indicate the available potassium levels of Vertisols and Fluvisols at the Haramaya University Research Farm of Ethiopia with varying levels of K-fixing capacity (unpublished).

Soil carbonates were reported to reduce the availability of micronutrients to plants and were negatively correlated with micronutrients [13]. It was observed that available $\mathrm{Fe}$ and $\mathrm{Mn}$ got precipitated on carbonates. Clay was found to be positively correlated with micronutrients. All micronutrients were negatively correlated with CEC. The competition of micronutrients for calcium reduced the metal ion sorption due to CEC. Based on test outlined by Lindsay \& Norvell [30], all the available $\mathrm{Fe}, \mathrm{Cu}$, and $\mathrm{Mn}$ were adequate, while $\mathrm{Zn}$ was found to be low in the soils studied by Fisseha [31]. Wekene \& Heluf [32] reported that in Nitisols (Alfisols) of Bako area, the available Fe and $\mathrm{Mn}$ concentrations in the surface soils were in toxic range, whereas available $\mathrm{Zn}$ content was deficient particularly in the research farm soils due to continuous harvesting of crops. The available copper content was within the adequacy range, but the available B content was very poor in the soils. Other findings showed that the DTPA-extractable $\mathrm{Fe}, \mathrm{Cu}$ and $\mathrm{Mn}$ were found to be adequate while $\mathrm{Zn}$ was low in different soils of Ethiopia [13]. Dereje \& Mishra (unpublished) observed that the soil available $\mathrm{Fe}, \mathrm{Mn}, \mathrm{Cu}, \mathrm{Zn}$ and even B were adequately supplied in the soils developed on basalt near Addis Ababa.

Use of organic residues and manures is found to be profitable in the Ethiopian soils, though as a thumb of rule, incorporation of inorganic fertilizers showed significant improvement on soil fertility and crop yields. Among the various organic sources used, maize straw indicated negative impact on crop yield [33]. Such negative effect of maize straw on yield could be due to its high $\mathrm{C}: \mathrm{N}$ ratio (around 80 ) which might have caused immobilization. However, Belay et al. [34] observed that long term (five years) use of maize crop residue increased mean maize grain yield by 135 to $327 \mathrm{~kg}$ ha-1 (5.6 to $12.8 \%$ ) over the control on Vertisols of Alemaya area. Similarly, incorporation of maize residues every year for a period of 7 consecutive years (1988-1994) both with low (residual) and recommended rates of mineral $\mathrm{N}$ and $\mathrm{P}$ fertilizers [35] increased maize grain yields than without crop residue on two different soil types in eastern Ethiopian highlands (Table 6). Sorghum crop residue management for 7 consecutive years (Table 7) showed little effect on sorghum yield when applied sole [36]. However, applying sorghum crop residue with some amount of fresh applied and/or residual $\mathrm{N}$ and $\mathrm{P}$ fertilizers gave sorghum grain yield which was either at par or greater than its yield produced with the application of recommended rates of mineral $\mathrm{N}$ and $\mathrm{P}$ fertilizers every year on two different soil types in Alemaya area (Table 7).

Table 6: Mean (1988-1994) yield of maize as influenced by maize crop residue and varying rates of applied and residual NP fertilizers on two soil types in eastern Ethiopian highlands.

\begin{tabular}{|l|c|c|}
\hline \multirow{2}{*}{\multicolumn{1}{c|}{ Treatment* }} & \multicolumn{2}{c|}{ Grain yield (kg ha-1) } \\
\cline { 2 - 3 } & Entisols & Vertisols \\
\hline Maize crop residue application each year & 2269d & $1611 \mathrm{c}$ \\
\hline Crop residue + $1 / 2$ of recommended N \& P applied each year & $2709 \mathrm{bc}$ & $2158 \mathrm{~b}$ \\
\hline Crop residue + recommended rate of N \& P applied each year & $3115 \mathrm{a}$ & $2917 \mathrm{a}$ \\
\hline Crop residue + $1 / 2$ of recommended N \& P only during the first year & 2555c & $1845 \mathrm{c}$ \\
\hline Crop residue + recommended rate of N \& P only during the 1st year & 2835b & $2153 \mathrm{~b}$ \\
\hline
\end{tabular}

*Means within a column followed by the same letter are not significantly different at $5 \%$ probability level.

Source: Heluf et al. [71]. 
Table 7: Mean sorghum grain yield and \% increase over the control for 7 years (1988-1994) as influenced by sorghum residue, and applied and residual NP fertilizers on two soil types.

\begin{tabular}{|c|c|c|c|c|}
\hline \multirow{2}{*}{ Treatment* } & \multicolumn{2}{|c|}{ Vertisols } & \multicolumn{2}{|c|}{ Entisols } \\
\hline & $\mathrm{kg} \mathrm{ha}^{-1}$ & $\%$ Increase & $\mathrm{kg} \mathrm{ha}^{-1}$ & $\%$ Increase \\
\hline $\begin{array}{l}\text { No crop residue \& no N \& P } \\
\text { (control) }\end{array}$ & $917 \mathrm{c}$ & - & $1192 c$ & - \\
\hline $\begin{array}{l}\text { Sorghum crop residue } \\
\text { applied yearly }\end{array}$ & $990 \mathrm{c}$ & 8 & $1262 c$ & 6 \\
\hline $\begin{array}{l}\text { Crop residue }+1 / 2 N \text { \& } P \text { in } \\
\text { year } 1 \text { only }\end{array}$ & $1239 b$ & 35 & $1624 b$ & 36 \\
\hline $\begin{array}{l}\text { Crop residue }+ \text { full N \& P in } \\
\text { year } 1 \text { only }\end{array}$ & $1426 a$ & 56 & $1604 b$ & 34 \\
\hline $\begin{array}{c}\text { Crop residue }+1 / 2 N \& P \\
\text { each year }\end{array}$ & $1216 b$ & 33 & $1837 b$ & 54 \\
\hline $\begin{array}{l}\text { Crop residue }+ \text { full N \& P } \\
\text { each year }\end{array}$ & $1432 \mathrm{a}$ & 56 & $1858 b$ & 56 \\
\hline $\begin{array}{c}\text { No crop residue }+1 / 2 N \& P \\
\text { each year }\end{array}$ & $1229 b$ & 34 & $1807 \mathrm{~b}$ & 51 \\
\hline $\begin{array}{c}\text { No crop residue }+ \text { full } N \& \\
P \text { each year }\end{array}$ & $1415 a$ & 54 & $2189 a$ & 83 \\
\hline $\operatorname{LSD}(0.05)$ & 174 & - & 283 & - \\
\hline $\begin{array}{c}\text { Mean increase over the } \\
\text { control }\end{array}$ & - & 39 & - & 46 \\
\hline
\end{tabular}

Means within a column followed by the same letter are not significantly different at $5 \%$ probability level.

Source: Asfaw et al. [69].

Elias et al. [37] tested different organic materials for $\mathrm{N}$ and $\mathrm{P}$ and reported that the leaf litters contain $2.28-3.30 \% \mathrm{~N}$ and $0.15-$ $0.22 \% \mathrm{P}$, which are higher than that of animal manures. They also reported that maize straw contains $0.35-0.39 \% \mathrm{~N}$ and $0.03 \% \mathrm{P}$, teff (Eragrostis tef) $0.6 \% \mathrm{~N}$ and $0.1 \% \mathrm{P}$, haricot bean $0.65 \% \mathrm{~N}$ and $0.03 \% \mathrm{P}$ and enset $1.89 \% \mathrm{~N}$ and $0.15 \% \mathrm{P}$. Tesfu \& Laktionov [38] observed that cultivation altered the forms of humus and its colloidal properties when compared with that of uncultivated soils leading to considerable decline of organic matter contents in the upper layers of cultivated soils. The pruning of Sesbania sesban was found to increase the yield of wheat significantly both over the control and fertilizer application [39]. Similarly, a secondary mineral, zeolite was found to have high selectivity and absorption capacity for ammonia and this can safely be used to cut down the $\mathrm{N}$-losses from fertilizer application [40]. Zeolite is a naturally occurring secondary mineral already found in Ethiopia in various places associated with basalt parent materials [41]. Thus, natural and indigenous resources can effectively be utilized for promoting the soil fertility to be derived from organic sources.

\section{Soil physical environment}

Table 8: $\mathrm{CO}_{2}-\mathrm{C}$ evolution ( $\mathrm{mg} \mathrm{C} \mathrm{g}^{-1}$ soil) as a function of varying clay contents in amended and un amended soils.

\begin{tabular}{|c|c|c|c|c|c|c|c|c|}
\hline \multirow{2}{*}{ Treatment } & \multicolumn{8}{|c|}{ Clay content $(\%)$} \\
\hline & 56.0 & 44.8 & 33.6 & 28.0 & 22.4 & 16.8 & 11.2 & 5.6 \\
\hline Control (un-amended) soil & 29 & 31 & 35 & 35 & 36 & 37 & 38 & 40 \\
\hline Tobacco starch-amended soil & 103 & 114 & 120 & 121 & 118 & 120 & 127 & 141 \\
\hline Barley straw-amended soil & 97 & 103 & 108 & 100 & 101 & 103 & 110 & 118 \\
\hline
\end{tabular}

Source: Mtambanengwe et al. [44] 
The rate of decomposition and net mineralization of soil organic matter depends on the accessibility of organic substrates to soil microorganisms [42]. The protective action by clays against organic matter degradation through the formation of complexes between metal ions associated with large clay surfaces and high CEC [43] was experienced to be one of the major causes of partially decomposed soil organic matter in basaltic soils of Ethiopia. It is also understood that the fine textured soils contain higher amount of organic matter than the sandy soils. The clay particles protect the more easily decomposable organic compounds from rapid microbial breakdown [44]. Mtambanengwe et al. [45] reported that carbon mineralization decreased with increasing clay content both in the control and the soils amended with tobacco starch and barley straw (Table 8). As indicated in the Table, evolution of $\mathrm{C}$ as $\mathrm{CO}_{2}$ ranged from $29 \mathrm{mg} \mathrm{Cg}^{-1}$ soil (56\% clay) to $40 \mathrm{mg} \mathrm{Cg}^{-1}$ soil (5.6\% clay) in the control soil and from $103 \mathrm{mg} \mathrm{Cg}^{-1}$ soil (56\% clay) to $141 \mathrm{mg} \mathrm{Cg}^{-1}$ soil (5.6\% clay) in the tobacco starch amended soil. Evolution of $\mathrm{CO}_{2}$ from the soil amended with barley straw also followed the same pattern (Table 8). Ladd et al. [46] reported a significant linear relationship between residual labeled $\mathrm{C}$ in the surface soil and clay contents ranging from 5 to $42 \%$ and concluded that the higher the clay content in different soils, the higher the residual C content.

Soil microorganisms live in the pore space of definite size. Hattori \& Hattori [47] reported that bacterial cells were present in pores of diameters varying from 0.8 and $6 \mu \mathrm{m}$. They suggested that the pores of a neck diameter of $2-6 \mu \mathrm{m}$ are favorable microhabitats for all bacteria. Hassink [48] reported a positive correlation between the habitable pore size fraction and the $\mathrm{N}$ mineralization. Adu \& Oades [49], however, opined that only a very small fraction of organic material in soil is in close proximity to the soil microorganisms in a given time. Mtambanengwe et al. [50] observed that the soil pores of diameters of less than $75 \mu \mathrm{m}$ were responsible for the protection of organic substrates against microbial decomposition in soils.

Bulk density was positively related to $\mathrm{C}$ mineralization whereas total porosity was negatively related [51]. Pore size distribution and continuity are the key factors influencing the soil water availability, gas diffusion and the migration of soil organisms [8,61]. Killham et al. [52] observed that substrate utilization by microbes in soil was strongly affected by pore size distribution and matric water potential. Montmorrilonitic clays in particular with their finer size and high CEC are more sensitive to complex formation with organic molecules and consequently, the products of organic matter decomposition are much more resistant for further decay [53]. It is also reported that the soil grinding would release carbon from both microbial biomass and from organic material itself. Grinding may kill about a quarter of the microbial biomass, which contributes to $25-50 \%$ of additional $\mathrm{CO}_{2}$ evolved on soil grinding.

\section{Trend of organic matter mineralization in soils}

Efforts have been made to enhance the carbon mineralization exhaustively. However, conflicting results had made such exercise discouraging. Kelly \& Henderson [54] reported that urea application did show little effect whereas super phosphate addition depressed the decomposition of white oak leaves (Quercus alba L.). Goyal et al. [55] reported that application of inorganic $\mathrm{N}$ fertilizer to wheat straw did not improve yield and yield attributes of the test crop. Nevertheless, Jones et al. [56] observed significant increase in yield and N-use efficiency when Leucaena leaf residues were combined with urea in 1:3 ratio. Considering the significant linear relationships between $\mathrm{N}$ mineralization and $\mathrm{CO}_{2}$ evolution for a number of organic residues $[56,57], \mathrm{CO}_{2}$ evolution is often used as a means of estimating the net N-mineralization. Kaboneka et al. [12] reported that the response of straw $\mathrm{C}$ decomposition to $\mathrm{N}$ fertilizer application followed the order: straw $+120 \mathrm{~kg}$ Nha-1=straw $+80 \mathrm{~kg}$ Nha ${ }^{1}>$ straw $+40 \mathrm{~kg} \mathrm{Nha}^{-1}>$ straw alone. Aligned to this, straw C decomposition as affected by P-fertilizer followed the order: straw+52.8kg $\mathrm{Pha}^{-1}>$ straw+35.2kg $\mathrm{Pha}^{-1}>$ straw+17.6kg Pha ${ }^{1}>$ straw alone. It is apparent that the combined use of low quality organic sources and inorganic nutrient materials are beneficial in enhancing organic matter decomposition and increasing total available nutrients for plants. The high and significant response of maize and sorghum grain yields to crop residue applied with recommended rates of $\mathrm{N}$ and $\mathrm{P}$ fertilizers on the first year or along with at least half of the recommended rates of NP every year (Tables 6 \& 7) also indicates the need for application of inorganic $\mathrm{N}$ and $\mathrm{P}$ fertilizers to enhance decomposition and release of nutrients from high $\mathrm{C}: \mathrm{N}$ ratio crop residues

\section{Turnover of soil organic matter}

The soil organic matter content exists in a state of dynamic equilibrium with break-down including the processes between accumulation and degradation. A change of just $1 \%$ of soil organic matter content (dry weight basis) may require an increase or decrease in the annual plant residue additions to the soil of about 2 tons per hectare over a one hundred year period. The extent of the gain or loss in soil organic matter content is virtually very small, unless there is a radical change to the rates of the microbial activities [58]. Turnover refers to the steady state involving the processes by which organic matter in soil may continually decompose and renew [59]. They derived a model as under:

\section{$\mathrm{TSOM}=[\mathrm{SOC}] /[\mathrm{IOOOC}]$}

where TSOM = turnover of soil organic matter, SOC = soil organic carbon ( $\mathrm{t} \mathrm{ha}^{-1}$ ) and IoOOC $=$ input or output of organic carbon $\left(\mathrm{t} \mathrm{ha}^{-1}\right.$ year $\left.^{-1}\right)$

The source of organic matter in soils may be the plant residues (litter, roots, branches, exudates) and manures. Roots 
alone provide huge amount of organic source often termed as Rhizo-deposition. Fogel [60] reported that $60-70 \%$ of the plant carbon is derived from the underground root system. The soil organic materials normally include decomposable and resistant materials, microbial biomass and physically and chemically protected organic materials. All these organic materials are in equilibrium in a given ecosystem and tend to come to a steady state. Carbon dioxide evolution is normally used as an indicator of the rate and direction of organic matter breakdown provided that the $\mathrm{CO}_{2}$ produced by root respiration is subtracted. By this is meant that the decomposition of organic materials results into return of organic carbon to the atmosphere as $\mathrm{CO}_{2}$ continuously. What is reasonable is to provide organic materials to soil continuously in a way to match with the loss of organic carbon from soils.

If a soil has 15 tones of soil organic carbon ha- ${ }^{-1}$, for example, under continuous cereal cultivation (causing organic matter decline), an annual application of 1.5 tones ha $^{-1}$ of organic carbon could bring the equilibrium to its minimum (steady state) for a period of about 10 years following the above model [61]. However, such model would need to be modified according to existing soil, crop and climate on long-term experimentation. Fractional computation indicated high turnover of the decomposable and resistant organic materials including microbial biomass whereas physically and chemically protected organic matters were very slow in their turn-over and so such protected organic matters predominant in many cases [34]. Soil organic matter in most of Ethiopian soils is liable to suffer from such protected organic materials [62]. Crops may respond to nitrogen fertilizers significantly in soils even with more than $3 \%$ organic carbon content. The clues are yet to be discovered and established for scientific exploitation of resources (Figure 1).

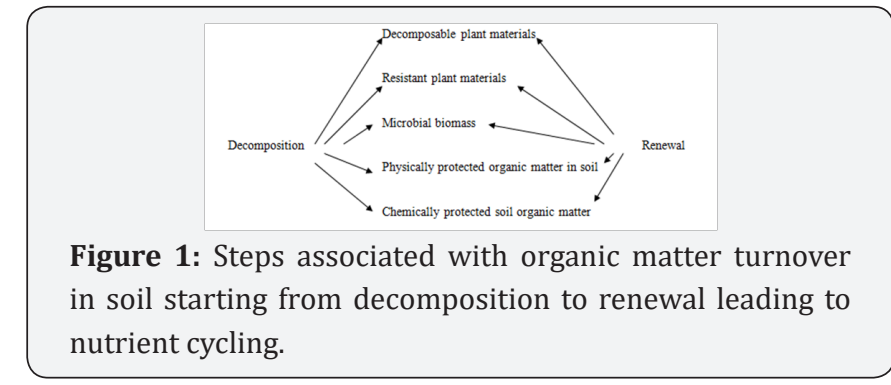

\section{Manure quality: some yardsticks}

The higher the nutrient content, the better is the quality of manure derived from organic sources. In other words, manure quality may be expressed as the value of manure in improving the soil properties and increasing the crop yields. The reviews by Kimani and Lekasi [63] have indicated that the quality of manures and so their usefulness as fertilizers is influenced by the management practices throughout their production cycles including the factors that affect the quality of feed the animals are fed, collection and storage methods, method of composting, method of application in the field and others. Laboratory analysis for nutrient contents is the scientific method to evaluate the quality of manure. The pattern of nutrient release and how the nutrient release rate could be adjusted with the crop uptake is another tool to decide the quality of manures. Chemical analyses for farmyard manures of different countries (Table 9) indicate wide variation in their nutrient contents [64] and this imposes challenge to accept the analytical value as the reliable yardstick for evaluation of the manure quality. Nutrient status of some organic manure used in Ethiopia is given in Table 10. However, farmers have their own traditional yardsticks to assess the quality of manure. As such, the immediate question is to match the scientist and farmer perceptions to come up with some simple decision tool for assessing the quality of manure.

Table 9: Chemical composition of farmyard manures from different countries.

\begin{tabular}{|c|c|c|c|c|c|}
\hline Country & N (\%) & P (\%) & K (\%) & Ca (\%) & Mg (\%) \\
\hline UK & 1.76 & 0.24 & 1.29 & 0.74 & 0.34 \\
\hline Madagascar & 1.10 & 0.80 & 0.86 & 0.85 & 0.40 \\
\hline Zimbabwe & 0.80 & 0.20 & 0.85 & 0.25 & 0.15 \\
\hline Kenya & 1.62 & 0.50 & 1.34 & 0.26 & 0.26 \\
\hline
\end{tabular}

Source: Kihanda and Gichuru [34].

Table10: Nutrient status of some organic manures used in Ethiopia.

\begin{tabular}{|c|c|c|c|c|c|c|c|c|c|c|c|c|}
\hline \multirow{2}{*}{$\begin{array}{c}\text { Organic } \\
\text { Manure* }\end{array}$} & \multicolumn{12}{|c|}{ Nutrient Content (\%) } \\
\hline & $\mathbf{N}$ & $\mathbf{P}_{2} \mathbf{O}_{5}$ & $\mathbf{K}$ & $\mathrm{Na}$ & $\mathrm{Ca}$ & Mg & Al & $\mathrm{Cu}$ & Mn & Zn & B & $\mathbf{C l}$ \\
\hline FYM & 1.40 & 1.64 & 0.14 & 0.27 & 1.19 & 0.93 & 0.09 & ND & 0.018 & ND & 11.75 & 0.63 \\
\hline $\mathrm{CH} / \mathrm{P}$ & 2.20 & 0.12 & 0.06 & 0.02 & 0.14 & 0.28 & 3.49 & ND & 0.044 & ND & 20.75 & trace \\
\hline Sisal & 1.40 & 0.36 & 0.17 & 0.02 & 5.06 & 0.25 & 0.06 & ND & 0.004 & ND & 105.50 & trace \\
\hline BM & 5.33 & 15.60 & 0.11 & 0.13 & 6.06 & 0.15 & trace & 0.001 & 0.001 & 0.01 & trace & 0.23 \\
\hline
\end{tabular}

${ }^{*} \mathrm{FYM}=$ Farmyard manure; $\mathrm{CH} / \mathrm{P}=$ Coffee husk/pulp; BM = Bone meal; ND = Not determined.

Source: Assefa Zeleke [2]. 
Farmers in some African countries use texture, longevity of composting, homogeneity, presence of fungi spores and hyphae as some of the criteria to define the quality of manures [65]. A quick judgment for selecting a green manure according to the existing requirements may be made by the farmers as suggested by Delve [48] in Figure 2. Wanjekeche et al. [66] reported some indicators of the good quality of manures used by farmers (Table 11). In the Tigray region of north Ethiopia, farmers distinguish between two manure "husse" and "aleba" based on the degree of their decomposition. The "husse" is well decomposed and thus rich in plant nutrients, whereas "aleba" is less decomposed with less nutrient contents [67]. It is also argued that the animals fed on high quality supplements produce high quality manures [8].

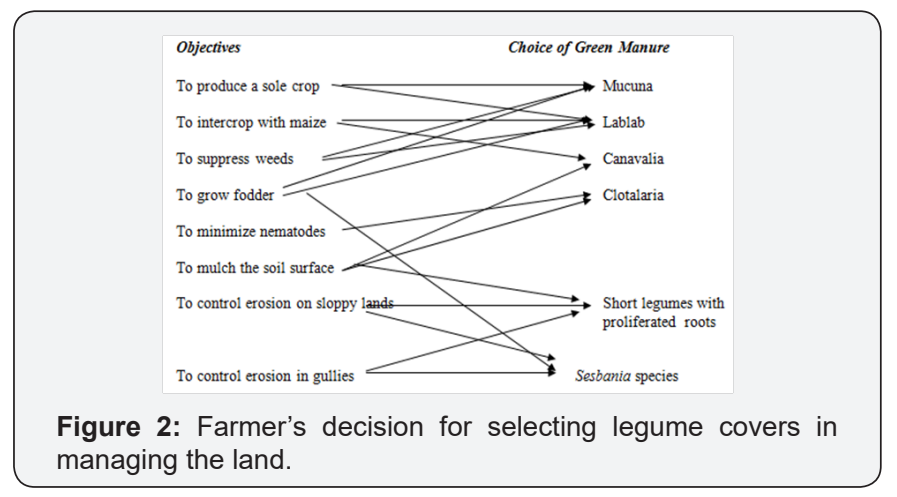

Table 11: Farmer's indicators for identifying good quality of manures.

\begin{tabular}{|c|c|}
\hline Indicator & Frequency of farmers \\
\hline Fine soil-like texture & 10 \\
\hline Black gray color & 12 \\
\hline Longer time for composting & 3 \\
\hline Appearance of white caterpillars & 5 \\
\hline Lack of heat in the manure & 2 \\
\hline
\end{tabular}

Source: Wanjekeche et al. [66].

Nhamo et al. [45] considered total nitrogen, lignin, C: N ratio, ash and organic carbon contents of the manures as valuable indices to evaluate the extent of net mineralized $\mathrm{N}$ and they forwarded a multifactor regression equation as below:

Net mineralized $\mathrm{N}=27.7 \mathrm{~N}+2.7$ Lignin+2.34 C: $\mathrm{N}+1.49$ Ash1.39 C-86.2

However, in manures low $\mathrm{N}$ contents, rates of up to $20 \mathrm{t}$ $\mathrm{ha}^{-1}$ gave an initial net $\mathrm{N}$ immobilization period during the first 7 days of incubation. The $40 \mathrm{t}$ ha- 1 treatment had positive net mineralized $\mathrm{N}$ for the entire incubation period. Hadas \& Portnoy [68] also reported that N, C and efficacy with which carbon is assimilated were vital in determining the mineralization of organic materials. Pathak \& Sarkar [39] reported that cattle manure with $0.79 \% \mathrm{~N}, 26 \mathrm{C}$ : $\mathrm{N}$ ratio and $27.5 \%$ ash content mineralized throughout the entire study period, whereas [25] observed that the manures with greater than $0.89 \% \mathrm{~N}$ content often mineralized throughout the entire incubation period.

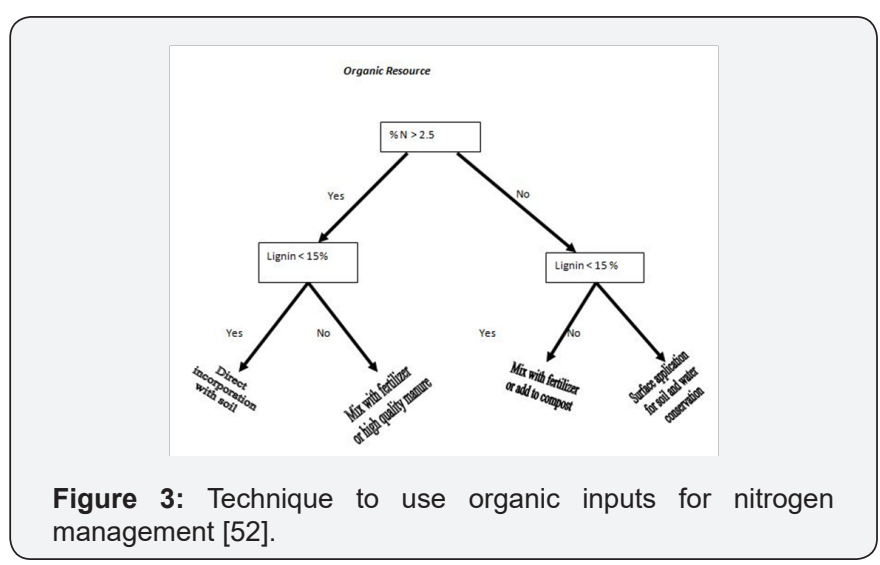

Studies on C:N ratio versus mineralization indicates that net mineralization was obvious from time zero up to 100 days for manures with C:N ratio of 13-22. However, manures with $\mathrm{C}: \mathrm{N}$ ratio above 30 indicated net immobilization throughout the period between zero and 100 days [46]. Manures may be of poor quality with total $\mathrm{N}$ being as low as $1.0 \%$, whereas most of the leguminous cover crops may have over 3.0\% N [69]. Kimani et al. [23] fractionated the low quality manure at 0:1:99 ratio of carbohydrate, cellulose and lignin, respectively. The same authors reported that improved quality manure was fractionated at 0:50:50 whilst the best quality manure had 33:33:34 ratio, respectively for carbohydrate, cellulose and lignin. At $\mathrm{C}$ : $\mathrm{N}$ ratio between 10 and 15, net $\mathrm{N}$-mineralization was recorded, whereas $\mathrm{C}: \mathrm{N}$ ratio of 25 and above did not show any mineralization preferably within a period of 100 days [27]. Accordingly, in order to increase the rate of decomposition and mineralization, the inorganic $\mathrm{N}$-fertilizer should preferably be mixed with the low quality organic N-source [48]. Such combination would improve synchrony of the N-released from the decomposing biomass and nutrient requirement by annual crops and reducing thereby the $\mathrm{N}$-losses [70]. Palm et al. [52], however, suggested a technique based on nitrogen, lignin and polyphenol contents of an organic resource to decide its applicability for nitrogen management (Figure 3) Nhamo et al. [50] reported that the manures with $\mathrm{C}: \mathrm{N}$ ratio less than 20 immobilized $\mathrm{N}$, which is consistent with results of Castellanos \& Pratt [6], who observed immobilization in manures with C:N ratio of 15.9 and $\mathrm{N}$ contents of $2 \%$. Such findings, of course, contrast with reports that C:N ratio of 23 behaves as the threshold for net mineralization [25-28]. Manures with $\mathrm{N}$ content greater than one percent mineralized while low $\mathrm{N}$ containing manures immobilized during the early stage of incubation [71]. Delve [23] forwarded a simple tool for identifying the quality of an organic resource for nitrogen management strictly in some farmer's language without looking for any laboratory data (Figure 4). This, however, needs to be validated further in Ethiopian conditions. 


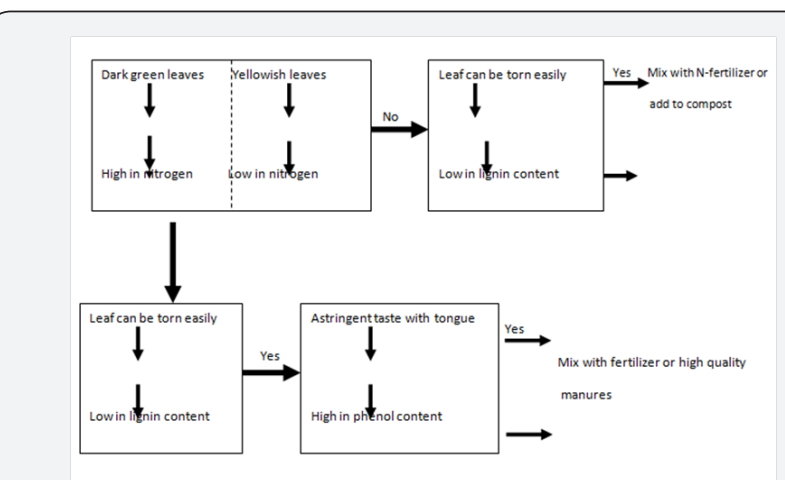

Figure 4: Sketch diagram of the different tied ridges and planting methods used in the study.

Fertilizer equivalencies (FE) of different organic sources may be the other option of quality evaluation of manures or any organic sources and this may be obtained by comparing the crop yield recorded from the given organic source treatments to that of the $\mathrm{N}$-response curve derived from $\mathrm{N}$-fertilizer. Mutuo et al. [48] obtained the $\mathrm{N}$-fertilizer equivalent for an organic source from the quadratic equation $\left(\mathrm{Y}=\mathrm{aFE}^{2}+\mathrm{bFE}+\mathrm{c}\right)$ as developed in the $\mathrm{N}$-response curves. In order to solve the quadratic equation, the formula used was:

$$
\mathrm{FE}=\left(-\mathrm{b} \pm \sqrt{ } \mathrm{b}^{2}-4 \mathrm{ac}\right) / 2 \mathrm{a}
$$

where $\mathrm{a}, \mathrm{b}$ and $\mathrm{c}$ are the constants. Kimetu et al. [37] derived a quadratic equation, $\mathrm{Y}=-0.0001 \mathrm{X}^{2}+0.0252 \mathrm{X}+1.8297\left(\mathrm{R}^{2}+0.9704\right)$ with values for $\mathrm{a}, \mathrm{b}$ and $\mathrm{c}$ being $-0.0001,0.0252$ and 1.8297, respectively. However, the fertilizer equivalencies (FE) of a given organic material can be calculated as below:

\section{$\% \mathrm{FE}=\mathrm{FE} /(\mathrm{N}$-added $) \times 100$}

where $\mathrm{N}$ added is the actual amount of $\mathrm{N}$ applied $(100 \%$ organic or inorganic or both).

\section{Immobisol as a proposed reference soil group of the world}

Table 12: Some relevant soil features of different pedons in Hirna watershed.

\begin{tabular}{|c|c|c|c|c|c|c|c|c|c|c|}
\hline Depth (cm) & $\begin{array}{c}\text { Coarse } \\
\text { fraction* }\end{array}$ & $\begin{array}{c}\text { Moisture } \\
\text { (\%) }\end{array}$ & $\mathrm{pH} \mathrm{H}_{2} \mathrm{O}$ & pH KCl & D Hp & EC dSm ${ }^{-1}$ & OC (\%) & OM (\%) & $\begin{array}{c}\text { Total N } \\
\text { (\%) }\end{array}$ & $\begin{array}{l}\text { C:N } \\
\text { ratio }\end{array}$ \\
\hline \multicolumn{11}{|c|}{ Toposequence 1: Back slope-up } \\
\hline $0-25$ & 37.55 & 9.78 & 7.28 & 5.77 & 1.51 & 0.041 & 2.14 & 3.69 & 0.038 & 56.32 \\
\hline $25-55$ & 20.33 & 9.3 & 7.53 & 5.85 & 1.68 & 0.062 & 2.13 & 3.67 & 0.107 & 19.91 \\
\hline $55-75$ & 17.19 & 11.91 & 7.65 & 6 & 1.65 & 0.06 & 2.23 & 3.84 & 0.071 & 31.41 \\
\hline \multicolumn{11}{|c|}{ Toposequence 1: Back slope-mid } \\
\hline $0-15$ & 37.75 & 12.38 & 6.89 & 6.66 & 0.23 & 0.067 & 4.25 & 7.33 & 0.197 & 21.57 \\
\hline $15-35$ & 33.17 & 12.28 & 7 & 5.82 & 1.18 & 0.047 & 2.76 & 4.76 & 0.079 & 34.94 \\
\hline \multicolumn{11}{|c|}{ Toposequence 1: Back slope-low } \\
\hline $0-25$ & 18.29 & 11.25 & 7.55 & 5.79 & 1.76 & 0.074 & 4.42 & 7.62 & 0.272 & 16.25 \\
\hline $25-60$ & 24.08 & 10.67 & 6.97 & 5.95 & 1.02 & 0.09 & 4.14 & 7.14 & 0.147 & 28.16 \\
\hline $60-90$ & 3.57 & 5.16 & 7.7 & 6.31 & 1.39 & 0.124 & 2.05 & 3.53 & 0.125 & 16.4 \\
\hline \multicolumn{11}{|c|}{ Toposequence 1: Foothill } \\
\hline $0-35$ & 12.55 & 9.12 & 7.01 & 5.49 & 1.52 & 0.085 & 2.89 & 4.98 & 0.137 & 21.09 \\
\hline $35-110$ & 0.42 & 9.6 & 7.1 & 5.59 & 1.51 & 0.079 & 2.35 & 4.05 & 0.123 & 19.1 \\
\hline $110-160$ & 8.99 & 10.67 & 7.68 & 5.76 & 1.92 & 0.092 & 2.2 & 3.79 & 0.039 & 56.41 \\
\hline $160-200$ & 1.54 & 9.58 & 7.98 & 6.44 & 1.54 & 0.243 & 0.8 & 1.4 & 0.054 & 15 \\
\hline \multicolumn{11}{|c|}{ Toposequence 2: Upland } \\
\hline $0-25$ & - & 6.13 & 7.02 & 5.87 & 1.15 & 0.151 & 1.66 & 2.86 & 0.089 & 18.65 \\
\hline $25-60$ & - & 12.41 & 6.93 & 5.67 & 1.26 & 0.09 & 3.59 & 6.19 & 0.086 & 41.74 \\
\hline $60-110$ & - & 8.46 & 7.49 & 5.78 & 1.71 & 0.106 & 2.54 & 4.38 & 0.083 & 30.6 \\
\hline $110-140$ & - & 7.45 & 8.04 & 6.42 & 1.62 & 0.174 & 1.63 & 2.81 & 0.09 & 18.11 \\
\hline $140-190$ & - & 6.36 & 7.91 & 5.6 & 2.31 & 0.256 & 1.49 & 2.57 & 0.067 & 22.24 \\
\hline \multicolumn{11}{|c|}{ Toposequence 2: Mid Land } \\
\hline $0-25$ & - & 8.71 & 6.95 & 5.65 & 1.3 & 0.118 & 1.23 & 2.12 & 0.137 & 8.98 \\
\hline $25-65$ & - & 6.8 & 7.2 & 5.5 & 1.7 & 0.085 & 2.46 & 4.24 & 0.052 & 47.31 \\
\hline $65-95$ & - & 10.74 & 7.64 & 6.05 & 1.59 & 0.109 & 2.25 & 3.88 & 0.046 & 48.91 \\
\hline $95-140$ & - & 11.25 & 8.23 & 6.67 & 1.56 & 0.284 & 1.3 & 2.24 & 0.086 & 15.12 \\
\hline
\end{tabular}




\section{Agricultural Research \& Technology: Open Access Journal}

\begin{tabular}{|c|c|c|c|c|c|c|c|c|c|c|}
\hline $140-180$ & - & 9.3 & 8.44 & 7.16 & 1.28 & 0.236 & 1.41 & 2.43 & 0.023 & 61.3 \\
\hline \multicolumn{11}{|c|}{ Toposequence 2: Low Land } \\
\hline $0-20$ & - & 9.79 & 7.02 & 5.63 & 1.39 & 0.133 & 3.08 & 5.31 & 0.084 & 36.67 \\
\hline $20-45$ & - & 6.78 & 7.08 & 5.47 & 1.61 & 0.081 & 2.99 & 5.15 & 0.112 & 26.7 \\
\hline $45-80$ & - & 11.51 & 7.46 & 5.97 & 1.49 & 0.091 & 3 & 5.17 & 0.109 & 27.52 \\
\hline $80-130$ & - & 11.12 & 8.37 & 6.85 & 1.52 & 0.273 & 1.73 & 2.98 & 0.093 & 18.6 \\
\hline $130-150$ & - & 11.57 & 8.22 & 6.82 & 1.4 & 0.28 & 196 & 3.38 & 0.086 & 22.79 \\
\hline $150+$ & - & 13.52 & 8.13 & 6.86 & 1.27 & 0.284 & 1.9 & 3.27 & 0.032 & 59.37 \\
\hline \multicolumn{11}{|c|}{ Toposequence 3: Foothill } \\
\hline $0-25$ & 21.15 & 7.43 & 6.66 & 5.45 & 1.21 & 0.072 & 1.68 & 2.9 & 0.09 & 18.67 \\
\hline $25-45$ & 5.59 & 7.13 & 6.74 & 5.27 & 1.47 & 0.059 & 2.76 & 4.76 & 0.06 & 46 \\
\hline $45-70$ & 2.73 & 8.34 & 6.99 & 5.32 & 1.67 & 0.055 & 2.58 & 4.45 & 0.076 & 33.95 \\
\hline $70-95$ & - & 8.2 & 6.97 & 5.47 & 1.5 & 0.06 & 2.15 & 3.71 & 0.098 & 21.94 \\
\hline $95-145$ & 0.83 & 12.36 & 7.34 & 5.67 & 1.67 & 0.058 & 2.37 & 4.09 & 0.079 & 30 \\
\hline $145-200$ & 5.93 & 9.02 & 7.45 & 6.12 & 1.33 & 0.095 & 1.7 & 2.93 & 0.084 & 20.24 \\
\hline \multicolumn{11}{|c|}{ Toposequence 3: Upland (AU Experimental Plot) } \\
\hline $0-30$ & - & 10.28 & 6.78 & 5.72 & 1.06 & 0.09 & 4.12 & 7.1 & 0.197 & 20.91 \\
\hline $30-70$ & - & 5.31 & 7.11 & 5.86 & 1.29 & 0.09 & 3.04 & 5.24 & 0.103 & 29.51 \\
\hline $70-105$ & - & 4.45 & 7.61 & 6.16 & 1.45 & 0.075 & 2.32 & 4 & 0.146 & 15.89 \\
\hline $105-140$ & - & 8.06 & 8.13 & 6.65 & 1.47 & 0.115 & 1.47 & 2.53 & 0.015 & 98 \\
\hline $140-195$ & - & 11.27 & 8.1 & 6.74 & 1.36 & 0.181 & 1.21 & 2.09 & 0.031 & 39.03 \\
\hline \multicolumn{11}{|c|}{ Toposequence 3: Mid land } \\
\hline $0-30$ & - & 9.3 & 6.66 & 5.52 & 1.15 & 0.091 & 3.03 & 5.22 & 0.115 & 26.35 \\
\hline $30-100$ & - & 10.51 & 7.56 & 5.87 & 1.69 & 0.09 & 1.77 & 3.05 & 0.093 & 19.03 \\
\hline $100-140$ & - & 11.78 & 7.02 & 6.72 & 0.3 & 0.228 & 1.61 & 2.77 & 0.039 & 41.28 \\
\hline $140-200$ & - & 5.64 & 8.19 & 7.08 & 1.11 & 0.251 & 0.74 & 1.27 & - & - \\
\hline \multicolumn{11}{|c|}{ Toposequence 3: Low land } \\
\hline $0-30$ & - & 6.21 & 6.8 & 5.57 & 1.23 & 0.108 & 4.14 & 7.14 & 0.156 & 26.54 \\
\hline $30-75$ & - & 10.63 & 6.89 & 5.47 & 1.42 & 0.075 & 3.15 & 5.43 & 0.101 & 31.19 \\
\hline $75-180$ & - & 10.55 & 7.94 & 6.33 & 1.61 & 0.136 & 2.89 & 4.98 & 0.131 & 22.06 \\
\hline
\end{tabular}

*Coarse fraction $(>2 \mathrm{~mm})$ is excluded in the data presented for different soil features.

Source: [22].

In Ethiopia, the soils derived from basalt and even limestones often show high C:N ratio (Table 12). Apparently, the soil organic matters present in such soils are directed towards immobilization. Such soils are very susceptible to the insect attack and this could be appreciated by the presence of common fine open or filled channels or holes called krotovinas as an indicator of biotic activities in soils. Such soils have subsequently been reported to be infected by insect pests and involve entomological exploitation to control against insect attack to the growing crops. The surface soils are normally granular to crumb in structure, whereas sub-surface soils show blocky structure of different grades. These soils are poor in total nitrogen, but indicate appreciable amount of available phosphorus [72]. They reported that the soils contain high clays $(>60 \%)$ with prominent manifestation of slickenside as well as clay skin, though the Gilgai micro-relief is virtually absent. Corrensite, attapulgite and iron-rich minerals were associated with interstratifications of smectite among the clay assemblage of these soils indicating almost well drained moisture conditions (unpublished). Immobisol is proposed to be a reference soil group of the world for such typical soils (Mishra \& Heluf, unpublished).

The soils often show high C:N ratio (Table 12) and the total soil $\mathrm{N}$ in general is around $0.05-0.10 \%$ (about $1000-2000 \mathrm{~kg}$ $\mathrm{Nha}^{-1}$ ). However, the crops were seen to respond to $\mathrm{N}$-fertilizers significantly. This indicates that the total soil $\mathrm{N}$ in these soils are virtually in organic forms possibly because of interlocking of organic material with clays and is not available to plants. Some basaltic soils have been identified to contain appreciable amount of zeolite in both silt and clay fractions (unpublished). This mineral is capable to promote the efficiency of nitrogen uptake by plants [73]. However, much of the efforts are desired to manage 
such soils, where organic carbon is physically and chemically protected. In one of such exercises, the soils were irradiated with
X-rays for ten times (each exposure of 0.5 second) to see the effect on $\mathrm{N}$ and $\mathrm{P}$ contents of soils (Table 13).

Table 13: Effect of X-rays on total nitrogen and available phosphorus contents of soils.

\begin{tabular}{|c|c|c|c|c|}
\hline \multirow{2}{*}{ Soil Properties } & \multicolumn{2}{|c|}{ Basalt Derived Soil } & \multicolumn{2}{c|}{ Limestone Derived Soil } \\
\cline { 2 - 5 } & Untreated & X-ray treated & Untreated & X-ray treated \\
\hline Total nitrogen (\%) & 0.140 & 0.189 & 0.420 & 0.451 \\
\hline Available P (ppm) & 27.12 & 28.99 & 17.98 & 21.02 \\
\hline
\end{tabular}

Source: Mishra and Heluf (unpublished).

\section{Steps towards fertilizer industry}

Fertilizers were first introduced in Ethiopia sometime in 1970 mainly with import of DAP and urea. Since raw materials for manufacturing chemical fertilizers were neither explored nor discovered, it has been only inevitable to produce fertilizers using locally available raw materials like slaughter-house wastes. With such wastes, attempts were made to manufacture single super phosphate (SSP), di-calcium phosphate and normal organic fertilizers. The raw materials for production of SSP are old bones and sulfuric acid, which are made available locally in Ethiopia. The organic fertilizers are produced through fermentation and biological transformation of all wastes of animal and plant origin by using bacterial ferment or simply by microorganisms (bacteria, fungi etc.). The ferments bring changes in any of the slaughter-house waste like sheep manures, paunch consent, blood, bones and meat, horns, hooves etc to natural fertilizers of high quality. Plant residues from agro-industries like wood dust, coffee husk/pulp, sugarcane residues, oil cakes and paper industry residues may also be combined with slaughter-house wastes to produce large amount of organic fertilizers.
Recently, Orga-P is locally produced and popularized in Ethiopia mainly as P-source for plants. On an average, Orga contains $23 \% \mathrm{P}_{2} \mathrm{O}_{5}, 21 \%$ calcium, $1 \%$ total nitrogen, $0.32 \%$ potassium, $0.30 \%$ magnesium, $0.012 \%$ zinc, $0.16 \%$ iron, $0.097 \%$ manganese, $0.233 \%$ sodium and $21 \%$ organic matter [74]. However, drought animals are believed to take offence to the smell of Orga. The authors have suggested using palygorskite (attapulgite) containing clays during processing of Orga in order to remove the offensive odor. This clay is commonly available in soils derived from basalt in Ethiopia (unpublished).

In line with organic fertilization, biogas technology is a new innovative approach in Ethiopia with its multi-directional uses such as light for house, gas for cooking and high quality manures. Livestock farming in Ethiopia is by and large common and promising and this facilitates the success of biogas technology. The bureau of Agriculture in Southern Region of Ethiopia planted more than 50 such biogas plants with promising results (Table 14). Dry sludge performed significantly better than both wet sludge and fresh manures, though the chemical fertilizers have an edge over all treatments.

Table 14: Effect of biogas sludge on crop production ( $\left.\mathrm{kg} \mathrm{ha}^{-1}\right)$.

\begin{tabular}{|c|c|c|c|c|c|}
\hline \multirow{2}{*}{ Crop } & \multicolumn{5}{|c|}{ Biogas Type } \\
\cline { 2 - 6 } & Control (no biogas) & Manure (fresh) & Biogas sludge (wet) & Biogas sludge (dry) & Mineral fertilizer \\
\hline Wheat & 1700 & 2000 & 2150 & 2500 & 4000 \\
\hline Maize & 3000 & 3800 & 4000 & 5000 & 6000 \\
\hline
\end{tabular}

\section{Second green revolution}

In terms of inherent land productivity, Ethiopia is undoubtedly a strong potential territory in the map of the world. However, in terms of actual production, it has to take its own course due to reasons enumerated recently by Mishra et al. [41,42] and Heluf et al. [21]. The first green revolution in Ethiopia could not receive appreciation due to lack of proper exploitation of the existing resources with limitations and unavailability of inputs. Meanwhile, the impacts of the excess use of fertilizers and chemicals including pesticides during the first phase of green revolution throughout the world do have now realization of pollution, food poisoning, inferior food quality, resistance of insects and diseases, soil sickness and overall human and livestock health hazards. People are now looking for food stuff throughout the world that should be natural and free from adulteration and toxicity. In this respect, one has to appreciate the existing state of production in Ethiopia with least or almost negligible impact of chemicals on food stuff. In this context, system approach for organic farming using only very limited amount of chemical fertilizers through proper integration would be encouraged with strong appreciation in this endeavor. Realization of this basic truth with Ethiopian agriculture would promote an international awareness leading to high value market to the Ethiopian products.

Besides, sand in the river basin, for example, may be very suitable for growing Cucurbits and even Saccharum species, a raw material for paper industry. Water in the river ditch may be made suitable for water-loving plants as practiced in some parts of India (Bihar). Breeding and varietals improvement 
through genetic and nuclear engineering or even biotechnology are possible to start with micro-level cultivation even on the roof of the building in metropolitan cities. Law must be imposed and implemented through municipality to develop the architect of a building knitted with a mini-farm on the roof of each building for growing at least green vegetables for daily use. This art must be combined with rain water harvesting on the roof of the building. Women empowerment is associated with such arts.

The uniform distribution of river water just from the points of their origin in the plains is a priority. The term "flood control" needs to be transformed with maximization of flood water in Table15: Mean grain yields ( $\mathrm{kg}$ ha-1) of sorghum and maize crops grown with and without NP fertilizers on four soil types: Alemaya series (Entisol), Alemaya black clay (Vertisol), Amaressa red soil (Alfisol) and Babile Sandy loam (Entisol) under the influence of tied ridges and planting methods between 1985 and 1994.

\begin{tabular}{|c|c|c|c|c|c|c|c|c|c|c|c|}
\hline \multirow{2}{*}{$\begin{array}{l}\text { Tied } \\
\text { Ridge } \\
\text { And } \\
\text { Planting } \\
\text { Method }\end{array}$} & \multicolumn{5}{|c|}{ Without NP Fertilizers* } & \multicolumn{5}{|c|}{ With NP Fertilizers* } & \multirow[t]{2}{*}{$\begin{array}{c}\text { Overal } \\
\text { Mean }\end{array}$} \\
\hline & Entisol1 & Vertisol & Alfisol & Entisol $^{2}$ & Mean & Entisol1 & Vertisol & Alfisol & Entisol2 & Mean & \\
\hline \multicolumn{12}{|c|}{ Sorghum variety ETS-2752 in the first three soil types and IS-9323 on Entisol2 } \\
\hline $\begin{array}{l}\text { Flat bed } \\
\text { planting } \\
\text { (control) }\end{array}$ & $3161 \mathrm{ab}$ & $1659 a$ & $1510 \mathrm{a}$ & $1214 \mathrm{a}$ & 1886 & $3943 a$ & $2588 a$ & $3459 a$ & $2491 \mathrm{a}$ & 3120.3 & 2503.2 \\
\hline $\begin{array}{l}\text { Open end, } \\
\text { planting } \\
\text { on ridges }\end{array}$ & $3026 a$ & 1918ab & 1571a & $1278 b$ & 1948.3 & 4137ab & $2841 b$ & $3516 a$ & $2649 b$ & 3285.8 & 2617.1 \\
\hline $\begin{array}{l}\text { Open end, } \\
\text { planting } \\
\text { in } \\
\text { furrows }\end{array}$ & $3559 \mathrm{~cd}$ & $2408 c$ & $1873 b$ & $1289 b$ & 2282.3 & $4708 c$ & $3275 d$ & $4135 c$ & $2897 \mathrm{c}$ & 3753.8 & 3018.1 \\
\hline $\begin{array}{l}\text { Closed } \\
\text { end, } \\
\text { planting } \\
\text { on ridges }\end{array}$ & $3432 \mathrm{bc}$ & $2180 \mathrm{bc}$ & $1584 a$ & $1525 c$ & 2180.3 & $4343 b$ & $3077 c$ & $3814 b$ & $2795 c$ & 3507.3 & 2843.8 \\
\hline $\begin{array}{l}\text { Closed } \\
\text { end, } \\
\text { planting } \\
\text { in } \\
\text { furrows }\end{array}$ & $3836 d$ & $2267 c$ & $2073 c$ & $1555 c$ & 2432.8 & $5304 d$ & $3843 e$ & $4608 d$ & $3174 d$ & 4232.3 & 3332.6 \\
\hline $\begin{array}{c}\text { Mean } \\
\text { yield of } \\
\text { sorghum }\end{array}$ & 3402.8 & 2086.4 & 1722.2 & 1372.2 & 2145.9 & 4487 & 3124.8 & 3906.4 & 2801.2 & 3579.9 & 2863 \\
\hline $\begin{array}{c}\text { Max. } \\
\text { increase } \\
\text { over flat } \\
\text { (kg ha-1) }\end{array}$ & 675 & 749 & 563 & 341 & 546.8 & 1361 & 1255 & 1149 & 683 & 1112 & 829.4 \\
\hline $\begin{array}{l}\text { Max. } \\
\text { increase } \\
\text { over flat } \\
\text { bed }(\%)\end{array}$ & 21.4 & 45.2 & 37.3 & 28.1 & 29 & 34.5 & 48.5 & 33.2 & 27.4 & 35.6 & 33.1 \\
\hline \multicolumn{12}{|c|}{ Maize variety EAH-75 in the first three soil types and Catumani on Entisol2 } \\
\hline $\begin{array}{l}\text { Flat bed } \\
\text { planting } \\
\text { (control) }\end{array}$ & 3978a & 4381b & $2756 a$ & $990 \mathrm{a}$ & 3026.3 & $4802 \mathrm{a}$ & $5944 \mathrm{c}$ & $4685 a$ & $2365 b$ & 4449 & 3737.7 \\
\hline $\begin{array}{l}\text { Open end, } \\
\text { planting } \\
\text { on ridges }\end{array}$ & $4280 \mathrm{~b}$ & $3647 a$ & 2861a & $1085 b$ & 2968.3 & $5367 \mathrm{~b}$ & $4877 \mathrm{a}$ & $5188 b$ & $2210 \mathrm{a}$ & 4410.5 & 3689.4 \\
\hline
\end{tabular}

non-flood zones being prone for drought. Agro-forestry in many parts of the country is less explored and discovered, though it has tremendous scope to cope with many agricultural risks. Diversification of plants in relation to soil and ecosystem needs to be re-defined in demand driven terms and such definition should be produced in dictionary form in order to enable people from other parts of the territory or even the world to validate or improve the utility of a plant identified for combating certain agricultural risk. Similarly, we have to look for many other plant species that can be used in natural resource management and such attempt should be envisaged globally. 


\section{Agricultural Research \& Technology: Open Access Journal}

\begin{tabular}{|c|c|c|c|c|c|c|c|c|c|c|c|}
\hline $\begin{array}{l}\text { Open end, } \\
\text { planting } \\
\text { in } \\
\text { furrows }\end{array}$ & $5135 c$ & $5143 c$ & $3569 b$ & $1352 \mathrm{c}$ & 3799.8 & $6089 c$ & $6954 d$ & $5562 \mathrm{bc}$ & $2550 \mathrm{c}$ & 5288.8 & 4544.3 \\
\hline $\begin{array}{c}\text { Closed } \\
\text { end, } \\
\text { planting } \\
\text { on ridges }\end{array}$ & $4464 b$ & $4228 b$ & $2605 a$ & $1438 c$ & 3183.8 & $5530 \mathrm{~b}$ & $5512 b$ & $4482 a$ & $2575 c$ & 4524.8 & 3854.3 \\
\hline $\begin{array}{l}\text { Closed } \\
\text { end, } \\
\text { planting } \\
\text { in } \\
\text { furrows }\end{array}$ & $5050 c$ & $5135 c$ & $3821 b$ & $1637 d$ & 3910.8 & $5710 \mathrm{~b}$ & $6778 d$ & $5944 c$ & $2778 d$ & 5302.5 & 4606.7 \\
\hline $\begin{array}{l}\text { Mean } \\
\text { yield of } \\
\text { maize }\end{array}$ & 4581.4 & 4506.8 & 3122.4 & 1300.4 & 3377.8 & 5499.6 & 6013 & 5172.2 & 2495.6 & 4795.1 & 4086.5 \\
\hline $\begin{array}{c}\text { Max. } \\
\text { increase } \\
\text { over flat } \\
\text { (kg ha-1) }\end{array}$ & 1157 & 762 & 1065 & 647 & 884.5 & 1287 & 1010 & 1259 & 413 & 853.5 & 869 \\
\hline $\begin{array}{c}\text { Max. } \\
\text { increase } \\
\text { over flat } \\
\text { bed (\%) }\end{array}$ & 29.1 & 17.4 & 38.6 & 65.4 & 29.2 & 26.8 & 17 & 26.9 & 17.5 & 19.2 & 23.2 \\
\hline $\begin{array}{l}\text { Mean } \\
\text { yield } \\
\text { of both } \\
\text { crops }\end{array}$ & & & & & 2761.9 & & & & & 4187.5 & 3474.8 \\
\hline
\end{tabular}

*Grain yield means of either sorghum or maize within the columns of unfertilized and fertilized Entisol1 (Alemaya series), Vertisol and Alfisol followed by the same letter are not significantly different at $P>0.01$ and that of Entisol2 (Babile sandy loam) at $P>0.05$.

Source: Heluf et al. [20].
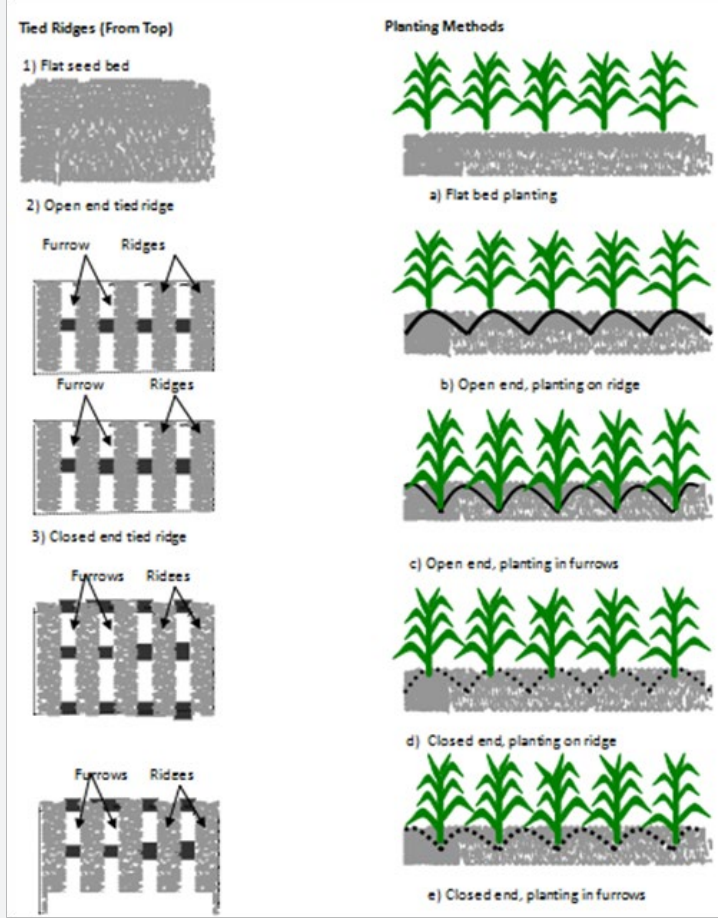

e) Closed end, planting in furrow

Figure 5: Simple tool for identifying organic resource for $\mathrm{N}$ management [10]. 
The highlands of Ethiopia with steep to gentle slope are subject to severe soil degradation (all physical, chemical and biological) and in many of the cases, the sustainability is at risk. What is of immediate interest is to follow zero tillage under intensive conservation measures [75]. Heluf et al. [20] observed an encouraging impact on minimizing the soil loss and increasing the maize yield (Table 15) where in the method (Figure 5) is recommended for sloppy lands for twin objectives of soil and water conservation. Following such conservation, zero/conservation tillage is highly recommended even before we look for organic farming with integrated nutrient management.

\section{Conclusion}

The agriculture in Ethiopia needs food security as well as food safety with rich nourishment so that the pillar of agriculture on soil must be installed on a common goal to productivity, profitability, and sustainability in agriculture. The first green revolution was basically targeted for higher yields whereas the second green revolution aims at quality improvement without degrading and polluting the land resource. The tremendous organic resources available in Ethiopia, particularly in the highlands, rather need to be exploited for their scientific utilization in maintaining as well as promoting the soil health and fertility status. However, integrated nutrient management by using minimum doses of inorganic fertilizers should only be encouraged in order to sustain the soil productivity without any scope of degradation, contamination, pollution, and even adulteration. The quality of foodstuff should be the central concept of the so-called second green revolution. Emphasis should also be given for complete replacement of conventional tillage by zero and/or conservation tillage concept particularly on sloppy highlands.

\section{References}

1. Cresser M, Killham K, Edwards T (1999) Soil chemistry and its application. Cambridge Environmental Chemistry. Series 5 Cambridge University Press, New York, USA.

2. Ladd JN, Amato M, Oades JM (1985) Decomposition of plant material in Australian soils. III. Residual organic and microbial biomass $\mathrm{C}$ and $\mathrm{N}$ from isotope labeled plant material and organic matter decomposition under field conditions. Aust J Soil Res 23: 603-611.

3. Micheni A, Kihanda F, Irungu J (2004) Soil organic matter (SOM): The basis for improved crop production in arid and semi-arid climates of eastern Kenya. In: Andre B (Ed), Managing Nutrient Cycles to Sustain Soil Fertility in Sub-Saharan Africa Academy Science Pub, Nairobi, Kenya, p. 239-248.

4. Food and Agriculture Organization (2001) Soil fertility management in support of food security in Sub-Saharan Africa. FAO, Rome, Italy.

5. Mulugeta S, Heluf G (2005) Effects of N and P fertilizers on yield and N uptake of flooded rice grown on Vertisols of Fogera Plain of Ethiopia. Indian Journal of Fertilizers 107: 161-176.

6. Wakene N, Heluf G, Abdena D, Geremew E (2005) Integrated use of farmyard manure, and $\mathrm{N}$ and $\mathrm{P}$ fertilizers for maize production under farmers conditions in Western Oromia. Indian Journal of Fertilizers 106(2): 131-141.

7. Murphy HF (1968) A report on the fertility status and other data on some soils of Ethiopia. College of Agriculture, Haile Sellasie I University. Experiment Station Bulletin No. 44. Dire Dawa, OSU-USAID Contract Publication, Ethiopia, 551.

8. Murphy HFA (1959) Report on the fertility status of some soils of Ethiopia. Imperial Ethiopian College of Agriculture and Mechanical Arts. Experiment Station Bulletin No 1: 201.

9. Desta B (1983) Micronutrient status of some Ethiopian soils. Science Bull 4: IAR, Addis Ababa, Ethiopia 43.

10. Knuti LL, Williams DL (1984) Profitable soil management. PrenticeHall Inc. New Jersey, USA.

11. Kang BT, Reynolds L, Atta K (1990) A.N. Alley farming. Advances in Agronomy 43: 315-359.

12. Kimetu JM, Mugendi DN, Palm CA, Mutuo PK, Gachengo CN, et al. (2004) Nitrogen fertilizer equivalency values for different organic materials based on maize performance at Kabete, Kenya. In: Andre B, (Ed.), Managing Nutrient Cycles to Sustain Soil Fertility in Sub-Saharan Africa. Academy Science Pub Nairobi, Kenya 207-223.

13. Mtambanengwe F, Mapfumo P, Kirchmann H (2004) Decomposition of organic matter in soil as influenced by texture and pore size distribution. In: Andre B (Ed.), Managing Nutrient Cycles to Sustain Soil Fertility in Sub-Saharan Africa Academy Science Pub Nairobi, Kenya 261-275.

14. Mugwe J, Mugendi D, Okoba B, Tuwei P, Neill OM (2004) Soil conservation and fertility improvement using leguminous shrubs in central highlands of Kenya: NARFP Case Study. In: Andre B (Ed.), Managing Nutrient Cycles to Sustain Soil Fertility in Sub-Saharan Africa. Academy Science Pub Nairobi, Kenya 277-297.

15. Young A (1989) Agro forestry for soil conservation. Intern. Center for Research in Agroforestry, ICRAF, Nairobi, Kenya.

16. Gachengo CN, Palm CA, Jama B, Otieno C (1999) Tithonia and senna green manures and organic fertilizers as phosphorus sources for maize in western Kenya. Agro forestry Systems 44(1): 21-35.

17. Palm CA, Gachengo CN, Delve RJ, Cadisch G, Giller KE (2001) Organic inputs for soil fertility management in tropical agroecosystems: Application of an organic resource database. Agriculture Ecosystems and Environment 83: 27-42.

18. Kaboneka S, Sabbe WE (2004) Evaluation of crop availability of K and $\mathrm{Mg}$ in organic materials under greenhouse conditions. In: Andre B (Edt.), Africa Managing Nutrient Cycles to Sustain Soil Fertility in SubSaharan. Academy Science Pub Nairobi, Kenya 163-171.

19. Nziguheba G, Palm CA, Buresh RJ, Smithson PC (1998) Soil phosphorus fractions and adsorption as affected by organic and inorganic sources. Plant and Soil 198(2): 159-168.

20. Phan TC (2001) Improving phosphorus availability in selected soils from the uplands of south Vietnam by residue management. A case study: Tithonia diversifolia. PhD Thesis No. 439 Katholieke University, Leuren, Belgium.

21. Paulos D (1996) Availability of phosphorus in the coffee soils of southwest Ethiopia. In: Proc. $3^{\text {rd }}$ Conf Ethiopian Soc Soil Sci 119-127.

22. Wakene N, Heluf G (2003) Forms of phosphorus and status of available micronutrients under different land-use systems of Alfisols in Bako area of Ethiopia. Ethiopian J Natural Resources 5: 17-37.

23. Heluf G, Mishra BB (2005) Pedogenic characterization of soils of Amensis Sub-Catchment of Hirna Watershed, West Hararghe. Agropedology 14.

24. Bockheim JG, Leide JE (1986) Litter and forest floor dynamics in a Pinus resinosa plantation in Wisconsin. Plant Soil 96(3): 393-406. 
25. Blair JM (1988) Nutrient release from decomposing foliar litter of three species with special reference to calcium, magnesium and potassium dynamics. Plant and Soil 110(1): 49-55.

26. Tariku G, Tekalign M (1999) Forms of soil potassium and its availability for sugarcane plant at Wonji Sugar Estate in Ethiopia. Ethiopian Journal of Natural Resources 1(1): 17-35.

27. Fisseha I (1996) Micronutrient status of three Ethiopian Vertisol landscapes at different agroecological zones. In: Proc. $3^{\text {rd }}$ Conf Ethiopian Soc Soil Sci, Addis Ababa, Ethiopia 153-161.

28. Lindsay WL, Norvell WA (1978) Development of a DTPA soil test for zinc, iron, manganese and copper. American Society of Agronomy 42(3): 421-428

29. Taye B (1996) Utilization of organic residues in Ethiopia: A review. In: Proc. $3^{\text {rd }}$ Conf Ethiopian Soc Soil Sci, Addis Ababa, Ethiopia 162-168.

30. Belay A, Gebrekidan H, Uloro Y (1998) Effect of tied ridges on grain yield response of maize (Zea mays L.) to application of crop residue and residual $\mathrm{N}$ and $\mathrm{P}$ on two soil types at Alemaya, Ethiopia. South African Journal of Plant and Soil 15(4): 123-129.

31. Heluf G, Asfaw B, Yohannes U, Eylachew Z (1999) Yield response of maize (Zea mays L.) to crop residue management on two major soil types of Alemaya, Eastern Ethiopia: I. Effects of Varying Rates of Applied and Residual N and P Fertilizers. Nutrient Cycling in Agroecosystems 54(1): 65-71.

32. Asfaw B, Heluf G, Yohannes U, Eylachew Z (1997) Effect of crop residues on grain yield of sorghum (Sorghum bicolor) (L.) to application of N \& P fertilizers. Nutrient Cycling in Agroecosystems 48(3): 191-196.

33. Elias E, Morse S, Belshaw DGR (1998) Nitrogen and phosphorus balance of Kindo Koisha farms in southern Ethiopia. Agric Ecosys Environ 71: 93-113.

34. Tesfu K, Laktionov HI (1996) Humus, its colloidal properties on soils around Ghinchi and Holetta. In: Proc. $3^{\text {rd }}$ Conf Ethiopian Soc Soil Sci, Addis Ababa, Ethiopia 111-117.

35. Coleman DC, Anderson RV, Cole CV, McClellan JF, Woods LE, et al. (1984) Role of protozoa and nematodes in nutrient cycling. In: Giddens JE, Todd RL (Eds.), Microbial-Plant Interactions. ASA Special Publication 47. SSSA Madison, USA 17-28.

36. Mishra BB, Heluf G, Kibebew K (2004) Soils of Ethiopia: Perceptions, appraisal and constraints in relation to food security. Journal of Food Agriculture \& Environment 2 (3-4) : 269-279.

37. Christensen BT (1987) Decomposability of organic matter in particle size fractions from field soils with straw incorporation. Soil Biol Biochem 19: 429-435.

38. Giller KE, Cadish G, Ehaliotis C, Adams E, Sakala W, et al. (1997) Building soil nitrogen capital in Africa. In: Buresh RJ, Sanchez PA, Calhoun F (Eds.), Replenishing soil fertility in Africa. SSSA Special Publication No 51, Madison, USA 151-192.

39. Paul EA, Veen JA (1978) The use of tracers to determine the dynamic nature of organic matter. In: Intern Cong Soil Sci Edmonton Trans $11^{\text {th }}$ Symposia Papers 3: 61-102.

40. Hattori T, Hattori R (1976) The physical environment in soil microbiology: An attempt to extend principles of microbiology to soil microorganisms. CRC Crit Rev Microbiol 423-461.

41. Hassink J (1992) Effects of soil texture and structure on carbon and nitrogen mineralization in grassland soil. Biology and Fertility of Soils 14(2): 126-134.

42. Adu JK, Oades JM (1978) Physical factors influencing decomposition of organic materials in soil aggregates. Soil Biol Biochem 10: 109-115(2).
43. Killham K, Amato M, Ladd JN (1993) Effect of substrate location in soil and soil pore-water regime on carbon turnover. Soil Biol Biochem 25(1): 57-62.

44. Russell EW Soil conditions and plant growth ( $9^{\text {th }}$ edn), John Wiley \& Sons Inc New York, USA 290-291.

45. Kelly JM, Henderson GS (1978) Effects of nitrogen and phosphorus addition on deciduous litter decomposition. American Society of Agronomy 42(6): 972-976.

46. Goyal S, Mishra MM, Hooda ES, Singh R (1992) Organic mattermicrobial relationships in field experiments under tropical conditions: Effects of inorganic fertilization and organic amendments. Soil Biol Biochem 24: 1081-1084.

47. Jones RB, Snapp SS, Phombeya HSK (1997) Management of leguminous leaf residues to improve nutrient use efficiency in sub-humid tropics. In: Cadisch G, Giller KE (Eds.), Driven by nature: Plant litter quality and decomposition CAB Int Wallingford, England, pp. 239-250.

48. Gilmour JT, Clark MD, Sigua GC (1985) Estimating net nitrogen mineralization from carbon dioxide evolution. American Society of Agronomy 49(6): 1398-1402.

49. Moorhead KK, Graetz DA, Reddy KR (1987) Decomposition of fresh and anaerobically digested plant biomass in soil. J Environ Quality 16(1): 25.

50. Kaboneka S, Nivyiza JC, Sibomana L (2004) Effects of nitrogen and phosphorus fertilizer addition on wheat straw carbon decomposition in a Burundi acidic soil. In: Andre B (Edt.), Managing Nutrient Cycles to Sustain Soil Fertility in Sub-Saharan Africa Academy Science Pub Nairobi, Kenya 151-161.

51. Jenkinson DS, Ladd JN (1983) Microbial biomass in soil: Measurement and turnover: In: Paul EA, Ladd JN (Eds.), Soil Biochemistry. 5: Marcel Decker, New York, USA.

52. Fogel R (1983) Root turnover and productivity of coniferous forests. Plant and Soil 71(1-3): 75-85.

53. Kimani SK, Lekasi JK (2004) Managing manures throughout their production cycle enhances their usefulness as fertilizers: A review. In: Andre B (Edt.), Managing Nutrient Cycles to Sustain Soil Fertility in Sub-Saharan Africa. Academy Science Pub, Nairobi, Kenya 187-197.

54. Kihanda FM, Gichuru M (1999) Manure management for soil fertility improvement. TSBF/AHI Report.

55. Kimani SK, Gachengo C, Delve R (2004) Simulated partitioning coefficients for manure quality compared with measured $\mathrm{C}$ : $\mathrm{N}$ ratio effects. In: Andre B (Edt.), Managing Nutrient Cycles to Sustain Soil Fertility in Sub-Saharan Africa. Academy Science Pub, Nairobi, Kenya 199-206.

56. Delve RJ (2004) Combating nutrient depletion in east Africa-the work of SWNM program. In: Andre B (Edt.), Managing Nutrient Cycles to Sustain Soil Fertility in Sub-Saharan Africa Academy Science Pub, Nairobi, Kenya 127-136.

57. Wanjekeche E, Mwangi T, Powon P, Khaemba J (1999) Management practices and their effects on nutrient status of farmyard manure in West Pokot district, Kenya. In: Proc $17^{\text {th }}$ Conf Soil Sci Soc East Africa, Kampala, Uganda.

58. Nhamo N, Murwira HK, Giller KE (2004) The relationship between nitrogen mineralization patterns and quality indices of cattle manures from different smallholder farms in Zimbabwe. In: Andre B (Edt.), Managing Nutrient Cycles to Sustain Soil Fertility in Sub-Saharan Africa. Academy Science Pub, Nairobi, Kenya 299-315.

59. Hadas A, Portnoy R (1994) Nitrogen and carbon mineralization rates of composted manures incubated in soil. J Environ Quality 23(6): 11841189. 
60. Pathak H, Sarkar MC (1994) Nitrogen supplying capacity of an Ustochrept amended in manure, urea and their combinations. J Indian Soc Soil Sci 42(2): 261-267.

61. Palm CA, Giller KE, Mafongoya PL, Swift MJ (2000) Management of organic matter in tropics: Translating theory into practice. Nutrient Cycling in Agroecosystems 61(1-2): 63-75.

62. Mugendi DN, Nair PKR, Mugwe JN, Neill OMK, Swift MJ, et al. (1999) Alley cropping of maize with Calliandra and Leucaena in the sub-humid highlands of Kenya. Part 2: Biomass decomposition, $\mathrm{N}$ mineralization and N uptake by maize. Agroforestry Systems 46(1): 51-64.

63. Castellanos JZ, Pratt PF (1981) Mineralization of manure nitrogencorrelation with laboratory indexes. Soil Sci Soc Am J 45: 354-357.

64. Frankenberger, WT, Abdelmagid HM (1985) Kinetic parameters of nitrogen mineralization rates of leguminous crops incorporated into soil. Plant Soil 87(2): 257-271.

65. Jansen BH (1996) Nitrogen mineralization in relation to C: $N$ ratio and decomposability of organic materials. Plant Soil 181: 29-45.

66. Quemada M, Cabrera ML (1995) Carbon and nitrogen mineralization from leaves and stems of four cover crops. Banner American Society of Agronomy 59(2): 471-477.

67. Swift MJ, Heal OW, Anderson JM (1979) Decomposition in terrestrial ecosystems. Studies in Ecology Volume 5. Blackwell Scientific Pub Oxford, UK, England 372.

68. NFMAC (2002) Orga fertilizer use and users guidance. National Fertilizer Manufacturing Private Limited Company, Addis Ababa, Ethiopia.
69. Heluf G (2005) Soil and water conservation practices (tied ridges and planting methods) on cultivated lands of eastern Ethiopian highlands: Experience of Soil and Water Research Program, Soil Science Technical Bulletin No. 2, Department of Plant Sciences AU Alemaya, Alemaya University, Ethiopia 124.

70. Heluf G, Mishra BB, Kibebew K (2005) Missing linkage in rainfall-runoffsoil water relationships for sustainable watershed development: A Case Study around Hirna, Eastern Ethiopia. J Food Agric and Environ 3.

71. Assefa Z (1996) Nutritional status and optimum NP rate studies for different organic fertilizer sources. In: Proc. $3^{\text {rd }}$ Conference of the Ethiopian Soc Soil Sci, Ethiopia 147-152.

72. Heluf G, Mishra BB, Aune JB (2005) Integrated soil-water-organic matter-nutrient management and conservation with no tillage in the sloppy lands of Ethiopia. Conservation Agriculture.

73. Mishra BB, Heluf G, Dereje T, Fikadu G (2002) Need for sustainable agricultural development in the collapsible land resources of the potentially rich Ethiopian highlands-Issues to be addressed. In: Proceedings of the Second International Conference on Sustainable Development of Agriculture for Food, Energy and Industry (SICSAFEI). Chinese Academy of Sciences, Beijing, China.

74. Mutuo PK, Marandu AE, Rabeson R, Mwale M, Snapp S, Palm CA (1999) Nitrogen fertilizer equivalencies based on organic input quality and optimum combinations of organic and inorganic N sources: Network trial results from east and southern Africa. In: SWNM Report on Combating Nutrient Depletion: East Africa Highlands Consortium.

75. Scott NA, Cole VC, Elliott ET, Huffman SA (1996) Soil textural control on decomposition and soil organic matter dynamics. American Society of Agronomy 60(4): 1102-1109.

\section{Your next submission with Juniper Publishers will reach you the below assets}

- Quality Editorial service

- Swift Peer Review

- Reprints availability

- E-prints Service

- Manuscript Podcast for convenient understanding

- Global attainment for your research

- Manuscript accessibility in different formats

( Pdf, E-pub, Full Text, Audio)

- Unceasing customer service

Track the below URL for one-step submission https://juniperpublishers.com/online-submission.php 